\title{
DOUBLE PORTRAITURE IN ART: THE COUPLE CONNECTION
}

\author{
RUTH DOROT \\ School of Architecture Ariel University, \\ Ramat Hagolan Str., Ariel, Israel \\ E-mail address: sf_moshed@bezeqint.net \\ ORCID: https://orcid.org/0000-0002-1884-1743
}

\begin{abstract}
Aim. The aim of this article is to examine and trace a selection of double portraits all adhering to social codes and norms, from the Renaissance to the present day depicting married couples who were well known in their day and highlighting that artistic fashion especially in northern Europe. Double portraits of a man and a woman are psychologically complex, since they usually provide a visual document of an emotional relationship. The artists' styles of presentation analyse the characters and relationships of the couples as well as their social status.

Methods. The method applied in this paper was that of a qualitative collective case-study based on specific paintings, the comparing and contrasting of which leads to general conclusions. Ten double portraits were selected. They portray well known figures and were painted by a variety of artists. In the second stage, the chosen works were sorted and catalogued chronologically to reflect diversity in terms of people, professions or status. Next, they were analysed on the basis of the language of plastic art: line, colour, light and shadow, composition and overall unifying organization.

Results and Conclusions. Since art reflects reality, I demonstrated the development of the field of double portraits across time and how it clearly reflects social change in the role and perception of the wife.

Parallel to the development and change in art from the 15th century to the present day, the topic of the double portrait has also changed; each era had its prevailing conventions in terms of fashion, customs, a woman's status, the development of technology and industry, freedom, liberation, and 'artistic license' that surprised, shocked and changed world orders. All these left their mark on the double portrait, which has come a long way from the height of formality to the hovering Chagall and Bella, or the selfannihilation of Picasso.
\end{abstract}

Key words: double portraits, frontal position, profile, domestic, communication, formal, Renaissance, surrealism, intimacy, Baroque, alienation. 


\section{INTRODUCTION}

The passage of time leaves its mark on people, who have always been dis1 turbed by the inability to control it. It is, perhaps, this frustration that led people's desire to be commemorated in art through portraits and self-portraits.

The camera, though only invented in 1826, seems to have been a primordial need accompanying humanity throughout history. In contrast, art historian Shearer West (2004) claimed that the double portraiture catered to social convention rather than to a "photographic" role. As early as in the Middle Ages, we could see the first instances of commemoration. Artists began to document donors to charitable causes in portraits and place them around the church or near the altar. Later on, as expounded on by philosophers Ruth Lorand (1992) and Maurice Merleau-Ponty (2004), portraits appeared in frescoes adorning certain palaces as well. The art of painting is also a form of research, wherein the research expresses the inner world of the subject. In his essay entitled L'oeil et l'espirit, Merleau-Ponty (2004) calls the painter a special kind of researcher because of his particular ability to see and expose the invisible.

The portrait is a work of art that represents a person's individual identity through a mimetic portrayal of facial features and social standing and, by penetrating more deeply, it succeeds in revealing character traits and the person's inner life. A portrait lies somewhere along a continuum between the specific resemblance and the general portrayal of the conventional type reflecting behavioural conventions originating in the socio-cultural milieu of the subject. Art historian Erwin Panofsky (1953) addressed this duality, saying that, by definition, a portrait has two channels: on the one hand, it aims to show what differentiates the subject from the rest of humanity or even from the subject himself or herself at a different time or in a different condition. On the other hand, it aspires to accentuate what the subject has in common with the rest of humanity (Panofsky, 1953).

Portrait painting began to flourish in Italy during the Renaissance as a result of the humanist worldview of man being at the centre of everything. Mostly the figures documented were young, beautiful, educated and from a respectable social class. At first, portraits were profiles cut off below the bust, but towards 1500 one can see the position and later on the full-front, full-length portraits. According to West (2004), the self-portrait involves intrapersonal discourse relating to self-discovery, the search for self-identity and self-analysis. The best known example in this context, is of course, the famous 17th-century Dutch master, Rembrandt van Rijn, who painted himself some 100 times at different ages in real and imaginary situations, in various costumes and roles.

From this point, the progression to double portraiture was only natural. Double portraiture, like the self-portrait, also manages to unearth a hidden layer in the hands of the artist. Psychoanalyst Donald Woods Winnicott (2002) who also addressed the notion of the "true self" lying beneath the many layers of the "false self," believed that the aspiration was to be able to touch that hidden, lonely and alienated inner nucleus, which at the same time is genuine and creative. 
Moreover, portraits also try to remove the image a person 'wears' - what Karl Jung referred to as the 'mask' that we don to hide, to protect our feelings, to conceal our secrets. Jung explored the concept of 'persona' originating in the mask worn in ancient Roman Theatre. One's private life and social life and their many roles require one to respond to society's various expectations. As a result, people forsake their inner truth and put on a 'mask.' Jung suggested that one should not forego the mask, but rather 'weave' it proportionally into one's experiences. When dealing with double portraits in particular, removing the private male, female and couple's mask is a difficult task. One of the roles of the double portrait painter is to see beyond the mask, to find the root of the figure and its truth, to seek that deep core that can reveal the inner world rather than just the outward image. Like the biographer who utilizes facts, stories, objects and the like, the portrait painter is a kind of biographer to some degree.

In Italy at the start of the 16th century and in the northern countries a century earlier not only saints and members of the aristocracy were being painted, but also two men, two women, a man and woman, either or both, with a child or an animal could be seen in portraits.

\section{PIERO DELLA FRANCESCA, DIPTYCH OF BATTISTA SFORZA AND FEDERIGO DA MONTEFELTRO 1474.}

While in an individual portrait the person takes up the whole space, in a double portrait the space is shared and the two figures compete for the observer's attention. In Italy, for example, prior to the appearance of the shared portrait, two separately framed paintings would be put side by side to create the couple portrait. Professor Dena Marie Woodall (2008) claimed that in many instances framed wooden boards were prepared in advance and the commissioned portraits were inserted at a later date. A well-known example of this is the portrait by Piero della Francesca (1416-1492) entitled Diptych of Battista Sforza and Federigo da Montefeltro 1474, demonstrating a social-artistic custom common during the Renaissance - that of commemorating the dead - that was linked to the epidemics common during the Renaissance period. The husband and wife are positioned at the forefront of the painting, with Federigo da Montefeltro on the right (observer's perspective) in profile, showing the left side of his face. This was contrary to the norm, because he wished to conceal his disfigured and blind right eye. Facing him is the image of his late wife, who died in 1472, copied from an earlier portrait. His vitality is contrasted with the pallor of his deceased wife's face. Art historian Lorne Campbell (1990) pointed out that since epidemics heightened the desire to commemorate the dead, portraits rose in popularity and offered a way of recording people for posterity. There is no eye-contact between the couple and the observer. Moreover, despite the physical proximity, there is no connection between the two figures which seem quite distanced from one another. Their clothes suggest wealth and dignity. 
The duke's red hat and matching topcoat highlight his commanding presence and power. His wife is bedecked with pearls and precious gemstones in addition to a translucent scarf intertwined in her plaits, indicating her status as a duchess.

\section{HANS MEMLING, TOMASSO DI FOLCO PARTINARI AND MARIA PARTINARI, 1470.}

This technique was also prevalent outside Italy, mainly in the northern countries, where the double portrait, according to Woodall (2008), was more important and more interesting. In Flanders, in 1470, Hans Memling (14301494) painted a double portrait of Tomasso di Folco Partinari and Maria Partinari. The portraits were probably commissioned by Tomasso in honour of his marriage in 1470 to the 14-year-old Maria. Their pose suggests prayer and their clothes, particularly her gown and necklace, indicate their wealth and social status. From here on, an artistic approach developed, in which the man and the woman share the space that visually documents the couple's relationship as well as social norms, image and status. In these two double paintings, there is no body language since the figures were artificially linked by the artists and did not pose for them as a couple.

Couples appearing in a common double portrait share a visual space in a shared frame that has no separation or partition. This mode of presentation prevents the exclusive dominance of either figure. According to Woodall (2008), such a portrait usually depicts secular purposes including marriage, mutual commitment, commercial agreements, commemoration of the dead, presentation of a family tree or family dynasty, intimate and sexual relations, and more. In this manner there is social dialogue and interaction between the two that is obvious to the observer via the eye contact and body language. The double portrait highlights certain facts or details about the image that either the subjects or the artist wish to preserve. It is from the reciprocity between the couple and the degree of balance between them (or lack thereof) that we learn about the superiority of one over the other. In the shared space, the men were usually positioned on the right, which was considered the positive side, while the women were positioned on the left. In reference to this, Woodall (2008 claimed that as a result, the superiority of men in terms of their social standing and status was visually prominent. It should be noted that in the mid16th century women were also respected due to their ability to give birth. One of the important characteristics of this genre that is indicative of the couple's connection is the way they look at each other and thence beyond the frame at the observer, as this is the key to the compositional mastery and ranking. In most cases, when the couple's gaze breaks through the boundaries of the frame or the painting, it is the man who holds the observer's attention. A woman's gaze in the observer's direction is somewhat diverted by the artist in order to convey the proper code of conduct. 


\section{JAN VAN EYCK, ARNOLFINI PORTRAIT, 1434.}

Art historian, Craig Harbison (1990), asserts that the visual enigma of The Arnolfini Portrait, 1434, by Jan van Eyck (1390-1441) - considered one of the masterpieces of the northern Renaissance - raises questions about the identity of the figures and the nature of the occasion. Another art historian, Carola Hicks (2012), maintains that this is an almost frontal, full-length double portrait of a couple, whose clothing and surrounding furnishings suggest they belong to the upper middle class. This style not only places the human figures centrestage, but is also notable in its precise detailing of the intimate space - the bedroom (Panofsky, 1934).

Their somewhat cold stance, which is formal, restrained and distant, and the position of their hands have given rise to differing scholarly opinions as to the event depicted and the identity of the figures. One supposition is that this is a wealthy Dutch textile merchant named Giovanni di Nicolao Arnolfini who lived in Lucca, Italy, and his wife Giovanna Cenami, who married in 1447 , some 13 years after the completion of this painting and some six years after the death of the artist. Hence this portrait presents an official event that is not necessarily a marriage, but perhaps an alliance between two respectable families, or even a political union. Panofsky (1934) claimed that certain details, such as the artist's formally calligraphed signature indicate that the painting is the formal documenting of the couple's secret wedding conducted in a private space before witnesses and that the woman was Constanza Trenta, who married Arnolfini in 1426 and died in 1433. According to Panofsky this was a practice later forbidden, where a couple could sign a legal and valid marriage agreement wherever and whenever they wanted, with no witnesses or religious ceremony, as long as mutual consent was given in writing and in deeds - an oath spoken with hands held and the groom's raised right hand. He believed this was a painting of an "act of marriage" and constituted visual confirmation of it (Panofsky, 1934). The formal agreement is validated by the couple's hands and by the artist's signature as a witness: "Johannes de Eyck fuit hic 1434 [Jan van Eyck was here]" (Panofsky, 1953). He added that there are those who disagree with his opinion about the marriage, but agree with him about the symbolic meanings of the painting that reinforce the connection. According to Margaret Koster (2003), these facts suggest that the painting might be a commemorative portrait of Constanza, completed one year after her death. This type of commemorative portrait is puzzling, as one of the figures is alive while the other is deceased. Panofsky (1953) points out that, the many household items in the painting contain hidden symbols such as the puppy symbolizing loyalty; Koster (2003) adds that the burning candle on the man's side of the chandelier suggests he is the one still alive, as opposed to the unlit candle on the woman's side, suggesting she is not. Moreover, art historian Benjamin Binstock points to the ten tiny medallions containing scenes of Christ's Passion embedded in the frame of the convex mirror on the back wall, two of which represent eternal life after his death. Those depicting the life of 
Jesus are located behind the man, while those depicting his death and resurrection appear on Constanza's side (Binstock, 2009). The version of it being a commemorative portrait is, therefore, supported especially when the couple's clothes is considered: the woman is wearing green - the colour of hope and love, and blue the color of loyalty, while the man is wearing dark clothing suggesting gravity and even mourning (Koster, 2003).

Campbell (1998) believed that the painting might be a souvenir intended to commemorate the marriage, but not to serve as legal witness to it. He considered the signature on the wall, with its rather notary-legal style, to be an accepted wall adornment at that time (Campbell, 1998). Perhaps the occasion does, indeed, document a marriage ceremony, given the gravity of the atmosphere and the serious attitude of the couple and the artist towards an official occasion with its committed tone indicating the sanctity of marriage. Harbison (1990) indicates that this sanctity is symbolized by the shoes that have been removed, as in the commandment (Ex. 3:5) "Take your sandals off your feet, because the place where you are standing is holy ground" (Common Jewish Bible).. Arnolfini's shoes are visible in the forefront of the picture, while his wife's slippers are at the far end of the room. The floor the two are standing on suggests a sacred union. Support for this supposition can be found in the marriage room - the sanctified atmosphere, which is reflected in the candle burning during the day, when artificial light is not necessary. The 'marriage candle' also fulfilled an essential role in ancient marriage rituals, to the point that the word 'candle' became synonymous for 'wedding'. In the current ceremony, a witness's reflection is visible in the convex mirror. The presence of the witness reinforces what is visible in the picture of the Passion, where, by marking Christ's torment, the artist hints at the reciprocal and religious commitment and the couple's mutual obligation to fidelity.

Another possible explanation is that van Eyck is portraying the marriage post facto for documentary purposes. Historian and author Edwin Hall (1994) who claimed that secret private marriages, even if performed before witnesses, were not considered legal in the absence of a clergyman, believed this was only a betrothal ceremony. His claim is based on the absence in the painting of a notary to verify the couple's consent, and the fact that the artist was not legally qualified to fulfil this function. Furthermore, the painting is not an official document, as it is missing a full date, and thus it is merely a visual document. The woman is not wearing a coronet on her head, as was the custom in first marriages both in Italy and in Flanders. Thus, the artist was witnessing a betrothal. Hall believed that the position of the arm and the hand, compared to what is known about marriage ceremonies in Holland at the time, does not support the hypothesis of a marriage ceremony, since the right hands are not clasped together in the painting. His conclusion is that this was a betrothal the families wished to remember, a ritual known as sponsalia, an alliance between two wealthy Italian families sealed in a ceremony without the sanctity or approval of the Church.

In contrast, author Margaret Carroll (2008) sees this work as an agreement in which the wife is granted the power to replace her husband in matters of busi- 
ness in his absence. She also considers the signature on the wall to be a notary approval. Positioning the husband by the open window may hint at his foreign travels for business purposes. The marriage connection is symbolized by the woman's head covering indicating her marital status, since unmarried girls wore their hair loose (Carroll 2008). Women surrounded themselves with symbolic objects they believed would be of help in the subject of procreation and enlargement of family. For this reason, Giovanna Cenami stands close to the red bed, a position alluding to her duty as a wife and future mother. Carroll went on to say that it was not by chance that the chair beside the bed is overseen by the sculpted figure of St. Margaret of Antioch, the patron saint of fertility and birth to whom expectant mothers prayed. Thus the figurine on the dresser is linked to the bride, just as the burning candle is connected to the groom Carroll (2008).

In accordance with custom, the woman stands barefoot by the bed while the red slippers, as mentioned, are at the far end of the room. Harbison (1990), who does not interpret the painting as a marriage ceremony, finds the gesture of the couple to be of a calming and even reverent quality, and notes that a bare foot is an almost universal symbol of lust and fertility, and that women had to touch the ground in order to become pregnant. In their Dictionary of Symbols, a philosopher and theologian Jean Chevalier and a writer, poet and explorer Alain Gheerbrant (1996) referred to the cherry tree visible in the courtyard outside the window as to a symbol of sexual desire like the oranges on the dresser and windowsill, signifying abundance, anticipation of fertility and even wealth, since they were imported from overseas. Before a newly-wedded couple fulfilled the commandment to enlarge the family, they would be fed sweets and fruits, which were supposedly a means of curing a pregnant woman's 'morning sickness' (Harbison, 1990).

An art historian Linda Seidel (1989) came to the conclusion that the painting was a riddle and that any interpretation of it was as good as any other. Her version, based on Tuscan marriages, is that Arnolfini entered Giovanna's room in order to consummate the marriage - symbolized by the red bed - a prerequisite for receipt of the dowry (ibid.). By offering his hand to his spouse, he is about to lead her to the physical bonding, not before he swears, by raising his right hand, to uphold the terms of the family agreement (Seidel, 1991).

All the possibilities mentioned above about the topic of the painting support the fact that it depicts some ritual between Arnolfini and his spouse, as the main detail in realist, legal and symbolic terms indicating an agreement, are the hands placed in the forefront undoubtedly expressing some kind of commitment. An art historian and literary critic Helen Gardner (1995), draws attention to the fact that the man's right hand is refined, elongated and raised in a pose of loyalty or oath to the agreement, representing a pose of authority that issues orders and commands while Fred Kleiner (2005) - a professor of History of Art and Architecture and Archaeology - emphasizes that in his left he holds her right hand in a submissive pose - low and flat, as was customary in the royal court of Burgundy. Hall (1994) supported the version of a betrothal, due to the hand gestures, which could not signify a marriage cer- 
emony because they in no way resembled what was prevalent at that time in Italy. In Flemish marriages, the man would firmly hold the bride's right hand in his right hand. Thus, he claimed that van Eyck shows an agreement or confirmation of a future marriage, in other words - a betrothal (Hall, 1994). In the event depicted, the groom-to-be takes his future bride's right hand in his left, since he swears an oath and defends his promise with his right. He goes on to state that the serious atmosphere emanating from the painting stems from the fact that while swearing this oath, he invokes God's presence to ensure that the reciprocal promise will be upheld (Hall, 1994).

One of the focal points of this debate is that Arnolfini is holding the woman's right hand in his left. Art historian Jan Baptist Bedaux (1986) claimed that this is, indeed, a marriage ceremony, and that the use of Arnolfini's left hand indicates a morganatic marriage, in which a man marries a woman of socially inferior birth. Most scholars disagree since Arnolfini and Giovanna Cenami bore equal status in the eyes of the law. There are some who believe that Giovanni Arnolfini actually raised his status by marrying Giovanna, who was wealthier than he was (Seidel, 1989). The mirror in the background reflects four figures: the couple, the artist and another figure acting as witnesses to the occasion. In addition to its contribution to creating light and depth in the painting, the mirror commemorates the ceremony as a historical document, just as the above-mentioned signature of the artist on the wall does.

\section{PeTER PAUl RUbens, THE ARTIST AND HIS FIRST WiFE, ISABELLA BRANT, IN THE HONEYSUCKLE BOWER, 1609.}

The virtuoso couple portrait, The Artist and his First Wife, Isabella Brant, in the Honeysuckle Bower, 1609, situated in the bosom of nature, is that of the 33-yearold painter Peter Paul Rubens (1577-1640) and his 18-year-old wife Isabella, who died in 1626 at the age of 33 . Love and affection are presented here as the basis of their union and engagement, and it is clear that both have freely decided to enter a marriage alliance, regardless of the legal aspect relating to property arrangements. However, we may discern that strong financial status coupled with a high social status and being well known, constituted the material basis for their relationship. The painter chose the landscape as a backdrop for their public appearance, despite its formality and elegance.

Rubens never portrayed himself as a painter, but rather as a nobleman, a gentleman, a diplomat or a wealthy member of society. Even in this couple portrait he is dressed elegantly - in luxurious stylish noble garments, especially prominent are the shiny orange satin stockings. He seems well-mannered, settled and calm - his left leg crossed over his right - seated slightly higher than his wife beside him. She is perched on her knees on the grass slightly closer to the observer, towards whom they are both gazing. Her smile is as light as her gaze, relaxed and friendly. The gemstone bracelet on her wrist indicates her family wealth. 
At first glance, Rubens appears manly and masterful, however almost immediately, the close connection between them is clear, highlighting the egalitarian nature of their relationship. Through small gestures, body language and subtle hints, the artist portrays a strong relationship based on mutual appreciation, satisfaction, a certain dependence on her part, and his pride at having her for his wife. A lacy grey band encircles her tall yellow Florentine hat, matching her decorative lacy neckline and grey cuffs which complement his lacy collar both in colour and texture.

Art historian Kristin Lohse Belkin (1998) draws the viewer's attention to the angle of their bodies leaning towards each other, in addition to how he is subtly touching the brim of her hat while his left hand holds a sword "as befits a nobleman" signalling their mutual kinship, while her gemstone-decorated left hand holds a fan (p. 96). In the centre, as pointed by art historian and researcher Hans Vlieghe (1998), her right hand meets his (dextrarum junctio) symbolizing the union of marriage and creating a close alliance between the symbolic and artistic form). In addition to this egalitarian pose, this meeting represents the official union in their engagement, as well as the profound gentleness expressed by his hand, which is casually wrapped in hers as it lays over his. It seems, as an art historian Norbert Schneider (1994) believes, that Rubens has slightly reduced the level of formality, but without diminishing its legalsymbolic significance.

Their closeness is also portrayed through the splendidly rich magenta folds of her puffed silk skirt, lightly touching a part of his right leg. There is even a certain physiognomic resemblance between their facial features, their pale pinkish skin, typical of the Flemish. Both are aware of their shared destiny and the value of their romantic life, although it is evidently lacking in sensuality.

For the backdrop, Rubens has chosen the Italian honeysuckle, which is a symbol of fidelity, love, devotion and generosity. Through the garden where the shrubs bloom in abundance like the floral embroidery on her corset, Rubens declares his happiness both as an individual and as a couple. Unlike van Eyck's Arnolfini couple, who are located in a room, Rubens has positioned himself and his bride in a 'Garden of Love' - in nature. The tradition of pastoral idyll together with its utopian hints of the Garden of Eden, is also resurrected in the literature of this period (Schneider, 1994).

During the 17th century, the social status of women was still inferior to that of men, and most relationships during this period were depicted in the art world as disharmonious. In light of this, Isabella's visual and moral prominence is notable, as is the distinguished position she holds as the painter's wife. The relationship between the two seems to be based on equality, although a certain hierarchy is implied as he is seated, while she kneels on the grass in front of him. 


\section{Peter Paul Rubens, Peter Rubens, his wife Helena} FOURMENT, AND THEIR SON, 1635 .

In his painting, Peter Rubens, his wife Helena Fourment, and their son, 1635, the artist portrays himself as a middle-aged man, still in the centre of the picture, but this time he is gazing not at the observer, but at his wife Helena, whom he married in 1630, when he was 53 and she was only 16. Rubens radiates authority and protectiveness towards her and their 3-year-old son, who is also looking up adoringly at his mother. This double portrait, which is more personal and more sensual than its predecessor, brings to the fore Helena's role as a wife and mother. Nevertheless, Rubens' loving and admiring gaze is meant for her alone. The parrot, a symbol of the Virgin Mary, suggests ideal motherhood, while the fountain in the background on the right, the caryatid, and the garden signify fertility and reinforce the notion of her in these roles.

Rubens celebrates their marriage with vibrant colours and figures filled with vitality by linking them to this garden of love, with his intimate expression and the gentle touch of his hand under hers, all testifying to their happiness. Her fair skin and the splendid brooch dangling from her ample bosom are the elements that made Helena a typical figure for Rubens, and, indeed, she was the model and the muse for many of his paintings. Unlike the preceding formal double portrait, this one bespeaks of idyllic domestic bliss and requited love, all displayed in Rubens' ornate baroque style, filled with the joys of life and uplifted spirits.

\section{JACQUES LOUIS DAVID, ANTOINE LAURENT LAVOISIER AND MARIE ANNE PIERETTE PAULZE, 1788.}

The French scientists, who married when he was 28 and she was 13, were painted by Jacques Louis David (1748-1825) in the portrait entitled Antoine Laurent Lavoisier and Marie Anne Pierette Paulze, 1788. They are painted in a space designed in an impressive neo-classical style, with a wooden floor and marble-like walls, surrounded by scientific laboratory equipment. Antoine, the multi-talented wealthy jurist, who was known as the 'father of modern chemistry' because he was the first to separate hydrogen from oxygen in water, is seated at his table, busy with some work-related writing. His left elbow is on the table covered with red velvet, on which there are papers and an inkwell holding two quills. Lavoisier is looking admiringly at his wife, a painter, professional colleague and lab assistant. He is dressed as a nobleman in a black waistcoat that is lightened by the surrounding whites and reds, the riding breeches, long stockings and buckled shoes, a white shirt with a lace collar and a powdered wig. Marie Anne, whose love of chemistry was well known, is standing very close to her husband, leaning comfortably on his right shoulder, while her right hand rests on the table. She is grandly 
attired in the fashion of the late 18th century: a white wig, a blue belt around an illuminated white gown with a lace collar, highlighting her presence and matching the softness of her features and her gaze turned in profile towards the observer.

On the left side of the room is a drawing board; on the right, on a porcelain bowl stands a jar containing water, probably to collect gas. Close to it is a test tube containing mercury used for measuring the concentration of oxygen in gases. To its left, a vessel for collecting mercury and on the floor a glass vessel for creating water out of oxygen and hydrogen. Next to it lies a hydrometer for measuring the specific gravity of liquids.

What makes this double portrait unique up to this point in general, and even in its own time, is the portrayal of the pair in their professional capacity, which was their principal activity. In Jacques Louis David's painting, one can sense the closeness and intimacy of this highly intelligent and sensitive couple from the expression on their faces. The painting reveals the artists' esteem and fondness for this couple and the extra importance afforded to Marie Anne, who stands taller and closer to the observer than her husband - a very uncommon occurrence given the norms of the period. It seems, as author and researcher Catharine C. Haines (2001) observes, that she has earned this esteem because of her involvement in scientific endeavours. As an art student of Jacques Louis David, Marie Anne Paulze was a master of drawing and used this skill while in her husband's laboratory, making notes in his notebooks, accurately sketching diagrams of experiment plans and equipment, up to the point where 13 sketches of the equipment her husband was using, helped others to understand his methods (Haines, 2001). In addition, she would edit his reports and the documentation of his work processes, and thus the couple developed the field of chemistry. Thanks to her mastery of French and Latin, Marie Anne even translated international research papers into French, critiqued scientific conclusions, and, in certain cases, even uncovered mistakes (Haines, 2001). This helped her husband keep abreast of developments in his field. On one topic it was her translation into French that convinced him in a case of an erroneous essential conclusion, a recognition which consequently led him to the discovery of oxygen. She also edited and published his memoirs and left her mark on many of his studies and papers. In 1789 she helped publish a new, ground-breaking theory in chemistry the publication of which included her own diagrams describing the experiments and the laboratory equipment.

The traits of her independent personality and her contribution to her husband's work led to their egalitarian relationship, and perhaps even caused the artist to give her a more central and honoured position than her husband's in this double portrait. It is possible that this change in the status of the wife at that time was linked with the early winds of the French Revolution. 
EDGAR DEGAS, EDMONDO AND THÉRÈSE MORBILI, 1865-1867.

The couple, a duke and duchess, portrayed in a realistic style in colours reminiscent of photographic sepia gives off an air of distance and alienation in the painting entitled Edmondo and Thérèse Morbili (1865-1867) by Edgar Degas (1834-1917). The intellectuals Edmondo and Thérèse Morbili are portrayed in their misery, with each of them feeling quite alone.

The Neapolitan gentleman, Thérèse's cousin who married her in 1863, is seated against a greenish background that seems closer to the observer than the grey background behind the woman with a black line dividing the two. Edmondo takes up some two-thirds of the picture both vertically and horizontally, his body almost full length, facing the observer as if moving in that direction. His face shows anger and his body language radiates presence, importance and self-esteem; his apparel is elegant and restrained. His left shoulder and knee are sharply defined; his elbow and the corner of the table on which his right hand is placed, as well as the chair placed in a sharp angle - all hint at this sharp and aggressive aspect of his personality. His gaze is focused on some distant point while his thoughts are detached from the intimate domestic reality he should be sharing with his spouse.

In contrast, Thérèse, Degas' sister, is seated behind a table, in the literal and metaphorical shadow of her husband. She radiates modesty, shyness and reluctance to be in the limelight, quite unlike Edmondo's condescending look stemming from his great self-confidence. Physically much smaller than her husband, Thérèse's bland personality is reiterated in her grey dress decorated with black and white monotones. The only thing linking them is the parallel between the colour of her dress and the grey of his trousers, between his black jacket and cravat and her black hair and the black decorations on her dress. All this contrasts with the richly embroidered tablecloth. Her anxious eyes display panic and worry, heightened by the placement of her right hand on her cheek, while the other rests on her husband's shoulder as if seeking support and comfort, which are not forthcoming.

Using his keen eye and psychological skill to understand people's psyche, Degas had already revealed the disconnect between the couple in an earlier painting of the same name (1865). In that painting, in addition to Thérèse's expression of misery and the somewhat weary and cynical expression of her husband, the fact that although they are both seated on the same settee, there is still a great distance between them, as if between two different worlds. A hint of her pregnancy can be found in her more rounded face and puffed-up dress, and yet, despite the indications of a bright future, the disconnect remains evident. 


\section{MARC CHAGALL, BIRTHDAY, 1915.}

With a completely different tone to that of the previous couple, there is a sense of fresh spirit in the appearance of Bella as a key figure in the love life of Marc Chagall (1887-1985), as his muse elevating him above reality and enabling him to overcome routine. It is she who is the cause of their shared happiness and joy - their intoxicating union. All these appear in the double portrait entitled Birthday, 1915. This was according to Jackie Wullschlager's (2008) biography of Chagall the first painting to have the motif of hovering lovers to demonstrate the emotional enthusiasm that Bella and Chagall shared.

It portrays a relationship and the celebration of love based on fantasy, memory, symbolism, imagination and an attempt to experience the togetherness in an original and unique manner.

In this double portrait, Chagall shows how an innocent kiss and a small bouquet of flowers becomes a surprise. He surprises Bella in the space of their shared room with his acrobatic hovering, unexpected and almost realistically impossible to perform. Bella is the driving force behind Chagall's creativity, as he finds an original and unforgettable way to preserve an intimate moment that was almost banal. Chagall 'translates' inner emotions into external movement. Bella's amazement also surprises the observer. She is wearing a darkish dress with serrated white cuffs and collar, her wide-open eye expresses her wonderment, and when half of Marc's face unites with half of hers in a kiss she levitates off the floor. The 'bonds' of gravity are not applicable when the mutual attraction between the couple overwhelms them. This vivid painting is a combination of fantasy, magic and reality; it expresses the hope, love and lyrical emotions that Bella brought to the marriage, to which Chagall related by saying that all he needed to do was to open his window and blue air, love and flowers flowed in with her. He felt that she could really sense who he was, that she was his partner in his crazy inventions, which never seemed odd to her (Chagall, 1965). Bella's dominant role was that of a powerful muse in her husband's life. She was a brilliant, intellectual and very cultured. Wullschlager (2008) claimed that Marc was unaware of her control over him because of the fusion of their personalities which 'melted' into one another.

In her book, First Encounter, Bella recounted-how the walls adorned with scarves dizzied their heads. Thus they flew above the fields of flowers, shuttered houses, rooftops, courtyards and churches floating by below them. There is no doubt that here Bella is expressing in her typically lyrical prose the outburst of emotion the two experienced on that occasion, a day before their wedding, and her attitude towards his art, as something sacred.

\section{PABLO PICASSO, BUST OF A WOMAN AND SELF-PORTRAIT,} 1929.

In 1906, Pablo Picasso was determined to reinvent the portrait (pertaining to double portraits, as well) and push the boundaries of realism. The perspec- 
tive was flattened and the face became a series of dramatic angles. Picasso had intentionally misrepresented various aspects of a sitter's appearance, turning the portrait into an early work of cubist caricature. An author and Rhodes scholar, Jonah Lehrer (2009) remarked that "[d]espite the artistic license, the person in the painting is still recognizable. Picasso took the most distinctive features - and exaggerated them. Through careful distortion, he found a way to intensify reality" (p. 4) and added Picasso's observation that art is the lie that reveals the truth.

What is surprising is that such distortions often make it easier for us to decipher what we are looking at, particularly when these distortions are executed by a master. Studies show one is able to recognize visual parodies of people faster than an actual photograph. The area of the brain involved in facial recognition, responds more eagerly to caricatures than to real faces, since cartoons emphasize the very features that we use to distinguish one face from another the most prominent.

A surprising fact about Bust of a Woman and Self-portrait, is that although Picasso was highly egocentric and extremely self-confident, he does not place himself at the centre of this piece, which makes him hard to discern. On the surface near the observer one sees a 'portrait' of a woman cut off at the bust. Her profile and back appear simultaneously, with her face joining the two. Picasso often joined two opposite positions at the same time in a one- or twodimensional space: a frontal portrait and a profile portrait. This is how the different parts of the 'ego' were connected, so that with the help of the painting he renders possible the impossible.

The woman's body, neck and hair are very sharply defined, and her mouth is wide open as a jaw from which massive teeth protrude, while her tongue is red, pointed and aggressive. The entire figure bespeaks of violence and blood. Even the two a-symmetric circles depicting the eyes exude aggression. And what of the artist? He appears in a profile almost swallowed up by a framed bright red background behind that of the "woman," being "devoured" by her gaping mouth. It seems that with this self-dismissal the artist almost completely annihilates himself. Hence this painting is not an auto-portrait or "classical" double portrait but rather a complex and sophisticated psychological double portrait in the spirit of the 20th century.

The Surrealists, who used the world of dreams, the subconscious and illogical combinations, were influenced by psychoanalyst Sigmund Freud's (1953) concept of the connection between "eros" and "thanatos"; between love and death. Consequently, they saw the woman as a consuming and castrating element. In her article entitled "Surrealism's Praying Mantis and Castrating Women," art historian Ruth Markus (2000) draws a parallel between woman and the female praying mantis which, either during or immediately after mating, beheads the male and sometimes even devours and swallows it; hence a parallel between the female mouth and the "vagina dentata". In order to highlight this consuming quality, the artist was prepared to show himself in a vague profile and as a framed picture in the background. According to various 
mythologies, the praying mantis has an obvious ambivalence: it is simultaneously wondrous and sacred, demonic and destructive, and the female, with its mystical powers, represents at one and the same time, death and rebirth. Scientists claim that the beheading leads to successful fertilization because of the male's trembling, and that the female needs extra nutrition during the act of mating. The surrealists, who were unaware of the scientific explanation, reinforced the myth and linked the praying mantis with the devouring female (Markus, 2000).

In various cultures, the female is linked with teeth, as a healer of pain and as a symbol of nutrition and digestion, but those same teeth also signify cannibalism and castration. Since the woman's mouth in this painting is full of threatening eyeteeth and possesses a serrated vagina that will castrate anyone who enters or penetrates, the "vagina dentata" became a key topic for the Surrealists. According to Picasso's friend, writer and biographer Pierre Daix (1994), the artist was expressing his attitude towards women through their teeth, with this painting reflecting the violence in his own home, based on the insulting screams of his wife Olga.

\section{SALVADOR DALÍ, SELF-PORTRAIT WITH GALA IN THE MIRROR, 1972.}

In art as in life, Salvador Dalí (1904-1989) broke with conventions and forged new artistic languages and methods capable of examining human psychology.

Salvador Dalís most direct contribution to and influence on psychology has been in the field of perception where his paintings have been used to demonstrate figure-ground illusions, perceptual reconstruction and surrealistic images.

Far beyond simply using dreams as a source of inspiration, Dalí, in fact, proactively harnessed the power of dreams, incorporating several systems of dream control into his artistic methods. Of his many techniques, perhaps his most famous is the "slumber with a key" (Dalí, 1948, p. 33). "This is a very brief nap less than a quarter-of-a-second long used to channel the fluid space between wake and sleep, where sensations and perceptions of the day re-surface as hypnagogic images leading to sleep. The afternoon slumber provides both visual inspiration and the necessary rest for the mind and hand, to stay sharp and steady for the labors of painting" (Dalí, 1948, p. 33). His instructions for the "slumber with a key" are as follows:

"You must seat yourself in an armchair, with your head tilted back and resting on the stretched leather back. Your two hands must hang beyond the arms of the chair, to which your own must be soldered in a supineness of complete relaxation. ... In this posture, you must hold a heavy key which you will keep suspended, delicately pressed between the extremities of the thumb and forefinger of your left hand. Under the key you will previously have placed a plate upside down on the floor ... The moment the key drops from your fingers, 
you may be sure that the noise of its fall on the upside down plate will awaken you" (Dalí, 1948, p. 33).

This procedure utilizes the muscle paralysis that naturally occurs upon falling asleep, causing the spoon to drop and startle you awake. Just before awakening you momentarily enter the hypnagogic sleep state, a state similar to REM sleep where the mind is fluid and hyper-associative, allowing creative connections to form, between seemingly remote concepts that you may not realize in the structure of waking thought. In other words, in this state your mind is able to bring together distant ideas in a new way.

But what drives these connections? Neurophysiologist Michelle Carr (2015) explains that intuition may provide the undercurrent to creative associations, drawing together memories and concepts through feelings of familiarity and sensed associations and that this idea has been explored also in the waking mind.

In their joined chapter Intuition, Incubation and Insight in G. Underwood's (Ed.), Implicit Cognition in Problem Solving, professor of music Jennifer Dorfman and psychologists Victor A. Shames and John F. Kihlstrom (1996), expounded even further: "[h]owever, in the waking state, subjects usually attempt to systemically search known associations in order to discover a solution, whereas in the hypnagogic state, intuitive hunches may naturally draw together new and unusual, distant associations" (p. 257).

A viewer sees the faces of Salvador Dalí and his wife, in Self-Portrait with Gala in the Mirror, 1972 (a shortened version of the name: Dali Seen from the Back Painting Gala from the Back Eternalized by Six Virtual Corneas Provisionally Reflected in Six Real Mirrors) as they are reflected in the mirror, and what's more - the "real portrait" has them with their backs to the observer. Did the artist mean that in his view a couple's relationship is nothing more than an illusion?

\section{CONCLUSION}

Art is a tool that explores the issue of double portraiture, which can be studied in terms of psychology, period, society, fashion, social standing, and the nature and quality of the couple's relationship. The couples analysed in the paintings, which serve as a written text, are portrayed according to the conventions of their day, and as such, they can be seen as a generalization of the genre in that they relate to intimate personal aspects, while at the same time representing other couples from the same location, period and social standing.

The artist is no longer dealing with the question of which side the man will be standing or the woman sitting on, nor which of the man's hands the woman will hold, and at what angle, since it is no longer about social standing, an official ceremony or a marriage alliance. For example, in the mischievous and unrealistic double portraits of Chagall, we can find the woman not beside the man but on his shoulders, not standing or sitting, but lying down or floating through the sky. One of the original examples of the revolution this topic 
underwent is evident in the double portrait of Salvador Dalís and the degree to which he challenges the conventions of the genre while still basing himself on the artistic tradition of The Artist in his Studio by Vermeer.

It seems that scientific and technological advancement, the shifting status of women and changes in social conventions, the greater permissiveness characterizing the 20th century - all these affect the ways couples are presented in terms of their interpersonal relations, their roles and their social standing.

Editing: Nili Laufert Translation: Micaela Ziv

\section{REFERENCES}

[1] Alexander, S. (1990). Chagall. Tel Aviv: Ladori Press (in Hebrew).

[2] Bedaux, J. B. (1986). The Reality of symbols: The Question of Disguised Symbolism in Jan van Eyck's 'Arnolfini Portrait'. Netherlands Quarterly for the History of Art, 16(1), 8.

[3] Belkin, K. L. (1998). Rubens. London: Phaidon Press.

[4] Binstock, B. (2009). Vermeer's Family Secrets: Genius, Discovery and the Unknown Apprentice. New York: Routledge.

[5] Bulwer, J. (2003). Chirologia or The Natural Language of the Hand .Whitefish, MT: Kessinger Publishers.

[6] Campbell, L. (1990). Renaissance Portraits: European Portrait Painting in the $14^{\text {th }}, 15^{\text {th }}$, and $16^{\text {th }}$ Centuries. New Haven, CT: Yale University Press.

[7] Campbell, L. (1998). The Fifteenth Century Netherlandish Paintings. London: National Gallery.

[8] Carr, M. (2015). How to Dream Like Salvador Dali. Psychology Today, Feb. 20. Retrieved from https://www.psychologytoday.com/us/blog/dream-factory/201502/ how-dream-salvador-dali

[9] Carroll, M. D. (1993). In the Name of God and Profit: Jan van Eyck's "Arnolfini Portrait". Representations, 44, 100-101.

[10] Carroll, M. D. (2008). Painting and Politics in Northern Europe: Van Eyck, Bruegel, Rubens and their Contemporaries. University Park: Pennsylvania State University Press.

[11] Chagall, B. (1987). First Encounter. New York: Schoken.

[12] Chagall, M. (1965). My Life. London: Peter Owen.

[13] Charles, C., Guerman, M., \& Forestier, S. (1996). Marc Chagall. New York: Parkstone Press.

[14] Chevalier, J., \& Gheerbrant, A. (1996). J. Buchanan-Brown (trans.), The Penguin Dictionary of Symbols. London: Penguin Books.

[15] Daix, P. (1994). Picasso Life and Art. London: Thames and Hudson.

[16] Dali, S. (1948). 50 Secrets of Magic Craftsmanship. Dover: Dover Publications.

[17] Digby, H. (1995). Rembrandt. London: Brompton Books.

[18] Dorfman, J., Shames V.A., \& Kihlstrom, J. F. (1966). Intuition, Incubation and Insight in G. Underwood, (Ed.). Cognition in Problem Solving, (pp.257-296). New York: Oxford University Press.

[19] Freud, S. (1953). The Theory of Instincts, The Standard Edition of the Complete Psychological Works of Sigmund Freud, XXIII. London: Hogarth Press.

[20] Haines, C. (2002). International Women in Science a Biographical Dictionary to 1950. California: Santa Barbara Press.

[21] Hall, E. (1994). The Arnolfini Betrothal, Medieval Marriage and the Enigma of Van Eyck's Double Portrait. Berkeley: University of California Press.

[22] Harbison, C. (1990). Sexuality and Social Standing in Arnolfini's Double Portrait, Renaissance Quarterly, 43(2), 249-291

[23] Hicks, C. (2012). Girl in a Green Gown. London: Vintage Books.

[24] Jung, C. G. (2014). Two Essays on Analytical Psychology. London: Routledge 
[25] Kleiner, F. S. (2005). Gardner's Art through the Ages. Boston: Wadsworth Publishing.

[26] Koster, M. L. (2003) The Arnolfini Double Portrait: A simple solution. Apollo 158 (499), 3-14

[27] Landsberger, F. (1946). Rembrandt, the Jews and the Bible. Philadelphia: The Jewish Publication Society of America.

[28] Lehrer, J. (2009). Unlocking the Mysteries of the Artistic Mind. Psychology Today, July 1. Retrieved from: https://www.psychologytoday.com/intl/articles/200907/ unlocking-the-mysteries-the-artistic-mind

[29] Lorand, R., (1991). On the Nature of Art. Tel-Aviv: Dvir Publishing House.

[30] Markus, R. (2000). Surrealism's Praying Mantis and Castrating Women. Woman's Art Journal, 21 (1), 33-39.

[31] Pallasmaa, J. (2005). The Eyes of the Skin: Architecture and the Senses. Chichester: Wiley \& Sons.

[32] Panofsky, E. (1934). Jan Van Eyck's “Arnolfini Portrait”. Burlington Magazine for Connoisseurs 64(372), 117-127.

[33] Panofsky, E. (1953). Early Netherlandish Painting: Its Origin and Character. Cambridge Mass.: Harvard University Press.

[34] Merleau-Ponty, M. (2004). L'oeil et L' espirit. In H. Kenaan (Ed.). Maurice Merleau-Ponty: L'oeil et L' spirit Trans: Eran Dorfman. Tel-Aviv: Resling Publishing House.

[35] Rosenberg, J. (1968). Rembrandt: Life and work. London: Phaidon Press.

[36] Schneider, N. (1994). The Art of the Portrait. Cologne: Benedikt Taschen Verlag.

[37] Seidel, L. (1989). Jan van Eyck's Arnolfini Portrait: Business as Usual? Critical Inquiry 16(1), 54-86.

[38] Seidel, L. (1991). The Value of Verisimilitude in the Art of Jan van Eyck. Yale French Studies, Special Issue, 25-43.

[39] Smith, D. (1982). Rembrandt's Early Double Portraits and the Dutch Conversation Piece. The Art Bulletin, 64(2), 259-288.

[40] Smith, D. (1986). "Courtesy and its Discontents: Frans Hals" ‘Portrait of Isaac Massa and Beatrix van der Laen'. Oud Holland, 100(1), 2-34.

[41] Vlieghe, H. (1998). Flemish Art and Architecture 1585-1700. New Haven CT: Yale University Press.

[42] West, S. (2004). Portraiture. Oxford: Oxford University Press.

[43] Winnicott, D. (2005). Playing and Reality. New York: Routledge.

[44] Woodall, D. M. (2008). Sharing Space: Double Portraiture in Renaissance Italy. Cleveland: Case Western Reserve University.

[45] Wullschlager, J. (2008). Chagall. New York: Alfred A. Knopf.

* The paintings captions were taken from free search online 